\title{
Komunikasi pariwisata dalam pengembangan destinasi wisata di Kecamatan Kuok Kabupaten Kampar
}

\author{
Yasir \\ Universitas Riau, Pekanbaru, Indonesia
}

\begin{abstract}
ABSTRAK
Pariwisata merupakan industri yang berkembang pesat secara global dan saat ini menjadi sumber pekerjaan dan mata pencaharian bagi banyak orang. Pembangunan pariwisata di daerah sebagai salah satu sektor pembangunan tidak dapat dilepaskan dari pembangunan masyarakat lokal dan pembangunan fasilitas pendukungnya. Salah satu faktor keberhasilan pengembangan sebuah destinasi wisata adalah komunikasi. Melalui komunikasi peluang keterkenalan suatu destinasi wisata akan terbuka semakin lebar dikenal oleh masyarakat luas. Penelitian ini bertujuan untuk menguraikan komunikasi pariwisata dalam pengembangan destinasi wisata dan menjelaskan partisipasi masyarakat dan memahami model perencanaan komunikasi pariwisata dalam pengembangan destinasi wisata di Kecamatan Kuok Kabupaten Kampar. Penelitian ini menggunakan metode kualitatif. Hasil penelitian menunjukkan bahwa komunikasi pariwisata pemerintah Kabupaten Kampar dalam mengembangkan destinasi wisata adalah dengan membentuk beberapa desa wisata, membina kelompok sadar wisata (Pokdarwis), dan mengembangkan partisipasi masyarakat pada daerah destinasi wisata yang melibatkan stakeholder pemerintah dan akademisi melalui pengabdian masyarakat. Simpulan penelitian menunjukkan bahwa Komunikasi pariwisata dalam pengembangan destinasi wisata Pulau Belimbing Kecamatan Kuok di Kabupaten Kampar dilakukan dengan cara membina dan memberdayakan kelompok sadar wisata (Pokdarwis), melibatkan partisipasi masyarakat sekitar destinasi wisata, dan kampanye wisata yang mengusung tema Wisata Agro-Cultural. Adapun saran nya adalah sebaiknya perencanaan komunikasi pariwisata di kawasan destinasi wisata Pulau Belimbing sebaiknya pemerintah mengembangkan komunikasi yang lebih kreatif, terintegrasi dan berkelanjutan dalam melakukan pembinaan menyesuaikan pada aspirasi masyarakat setempat.
\end{abstract}

Kata-kata Kunci: Komunikasi; pariwisata; destinasi; wisata budaya; desa wisata

\section{Tourism communication in the development of destinations in Kuok District, Kampar Regency}

\begin{abstract}
Tourism is a fast growing industry globally and is currently a source of jobs and livelihoods for many people. Regional tourism development as a development sector cannot be separated from the development of local communities and the construction of supporting facilities. One of the success factors in developing a tourist destination is communication. Through communication, opportunities for the fame of a tourist destination will be more widely recognized by the wider community. This study aims to describe tourism communication in developing tourist destinations and explain community participation and understand the tourism communication planning model in developing tourist destinations in Kuok District, Kampar Regency. This study uses a qualitative method. The results showed that the tourism communication of the Kampar Regency government in developing tourist destinations was by forming several tourist villages, fostering tourism awareness groups (Pokdarwis), and developing community participation in tourist destination areas that involved government stakeholders and academics through community service. The research conclusions show that tourism communication in developing tourist destinations for Belimbing Island, Kuok District in Kampar Regency is carried out by fostering and empowering tourism awareness groups (Pokdarwis), involving community participation around tourist destinations, and tourism campaigns with the theme of Agro-Cultural Tourism. The suggestion is that it is better if planning tourism communication in the tourist destination area of Belimbing Island, the government should develop a more creative, integrated and sustainable communication in conducting guidance according to the aspirations of the local community.
\end{abstract}

Keywords: Communication; tourism; destinations; cultural tourism; tourist village

Korespondensi: Dr. Yasir, M.Si. Fakultas Ilmu Sosial dan Ilmu Politik (FISIP), Universitas Riau. Jl. HR Soebrantas, Km 12,5, Pekanbaru. 28292.Email: yasir@lecturer.unri.ac.id 


\section{PENDAHULUAN}

Industri pariwisata dapat memengaruhi perkembangan ekonomi dan masyarakat sebuah negara (Fan et al., 2018; Strydom et al., 2019). Pariwisata juga dapat berkontribusi pada pertumbuhan ekonomi dan peningkatan sumber pendapatan masyarakat baik secara langsung maupun tidak langsung (Ali, 2018). Pariwisata saat ini telah menjadi industri besar dan salah satu industri yang berkembang pesat secara global serta menjadi sumber pekerjaan atau mata pencaharian bagi banyak orang. Oleh karena itu, bidang pariwisata memerlukan berbagai jenis inovasi, karena ini adalah salah satu sektor yang paling kompetitif (Genç \& Genç, 2017).

Pengembangan pariwisata bertujuan untuk memfokuskan kembali, merencanakan dan menerapkan kebijakan yang mendorong pengembangan sumber daya alam untuk memberi manfaat bagi masyarakat adat dan pemangku kepentingan lainnya yang mencakup pemerintah, industri, masyarakat dan para pengunjung itu sendiri. Oleh karena itu, komunikasi menjadi sangat penting untuk keberhasilan pengembangan sebuah destinasi wisata. Kebijakan komunikasi pengembangan destinasi wisata membutuhkan partisipasi aktif masyarakat (Yasir et al., 2019). Pembangunan pariwisata jelas memiliki peran penting dalam meningkatkan kesejahteraan penduduk lokal, karena dukungan penduduk setempat ini sangat penting bagi industri pariwisata. Keberadaan masyarakat yang didukung dengan kepemimpinan, inovasi dan sosial capital menjadi komponen penting dalam membangun destinasi wisata yang cerdas (Boes et al., 2016). Masyarakat menjadi pemangku kepentingan yang paling utama dalam proses pencapaian pembangunan berkelanjutan di bidang pariwisata (Lundberg, 2017). Selain itu, pengembangan komunikasi pariwisata juga harus berbasis budaya dan kearifan lokal dengan didukung dengan pelestarian dan pembangunan lingkungan berkelanjutan (Bakti et al., 2018).

Komunikasi pariwisata yang berbasis kearifan lokal mampu memberikan nuansa pembaharuan kegiatan wisata selama ini yang berorientasi pada hal-hal yang "modern" yang berbasiskan perkembangan ilmu pengetahuan dan teknologi. Model komunikasi pemasaran berbasis pada kearifan lokal, dilakukan dalam upaya untuk memberikan alternatif pemilihan destinasi wisata yang akan dikunjungi oleh para wisatawan (Nugraha et al., 2017).

Oleh karenanya, pembangunan pariwisata di daerah sebagai salah satu sektor pembangunan tidak dapat dilepaskan dari pembangunan masyarakat lokal dan pembangunan fasilitas pendukungnya. Karena persaingan pasar pariwisata yang ketat, maka sebuah destinasi wisata harus dapat dikembangkan melalui komunikasi yang lebih inovatif agar disukai oleh wisatawan, karena permintaan wisatawan bahkan lebih bervariasi bila dibandingkan dengan tahun-tahun sebelumnya (Genç \& Genç, 2017).

Pembangunan destinasi wisata memiliki peran penting dalam memelihara warisan budaya, kearifan lokal, dan kelestarian alam. Hal ini bisa dilihat penelitian terkait pariwisata budaya dan industri kreatif yang menjadi tren baru bagi wisatawan (Liu, 2018). Komunikasi pemasaran terpadu sangat dibutuhkan dalam mengembangkan destinasi wisata budaya (Wang et al., 2009). Meskipun kajian pariwisata sebelumnya sudah ada memberikan kontribusi signifikan terhadap penjelasan tentang bagaimana pariwisata meningkatkan pembangunan ekonomi lokal, namun mereka mengabaikan fakta bahwa perlindungan dan perluasan budaya juga memerlukan komunikasi untuk memberikan pemahaman, kesadaran lingkungan, dan pemberdayaan masyarakat. Bahkan program komunikasinya pun sering dimaknai berbeda. Penelitian terkait dengan ini menjelaskan bahwa saluran komunikasi yang terbentuk dalam pengembangan destinasi wisata berbasis kearifan lokal bersifat antarpribadi, kelompok yang kohesif dan media sosial, sehingga melahirkan kerja sama dalam memanfaatkan aktivitas budaya sebagai daya tarik wisata dan pengembangan programprogram terkait dengan pengembangan destinasi lainnya (Bakti et al., 2018).

Pembangunan pariwisata pada dasarnya berupaya mendorong para pelaku atau pemangku kepentingan di sektor pariwisata untuk saling mendukung. Masyarakat dilibatkan tidak hanya sekedar sebagai objek tapi juga sebagai subjek pembangunan, karena pembangunan kepariwisataan bersifat sistemik dan terpadu. Peran masyarakat secara aktif dalam kegiatan pariwisata dapat dilaksanakan secara langsung maupun tidak, baik secara perseorangan 
maupun secara bersama-sama (Ridlwan et al., 2017). Kesadaran dan partisipasi warga terhadap pembangunan pariwisata ini sangat penting karena berdampak langsung terhadap pembangunannya.

Lingkungan di pedesaan memiliki daya tarik wisata kekhasan akan keindahan alam dan budaya asli masyarakatnya. Wisata pedesaan dapat dikelola menjadi desa wisata karena atraksi, amenitas, dan kelembagaannya berasal dari inisiatif dan keinginan warga sendiri. Wisata pedesaan adalah bentuk dari wisata untuk kegiatan mengenang masa lalu (memorial), di samping juga sebagai bentuk mengalihkan kegiatan wisatawan dari rutinitas wisatawan sehari-hari, atau semacam menenangkan diri dari hiruk-pikuk kehidupan perkotaan. Hal ini lah yang menarik bagi desadesa di Kecamatan Kuok sebagai destinasi wisata untuk dikembangkan sebagai daya tarik dan solusi untuk wisata para wisatawan lokal dari Kota Pekanbaru yang jaraknya tidak terlalu jauh.

Salah satu persoalan yang mendasar dalam pembangunan dan peningkatan wisata di Kecamatan Kuok dan Kabupaten Kampar secara umum adalah kurang gencarnya penggunaan media komunikasi dan minimnya pengemasan produk penunjang objek wisata yang dikembangkan. Pengembangan komunikasi pariwisata dan pemberdayaan masyarakat dalam meningkatkan destinasi wisata belum dilakukan secara terintegrasi. Padahal komunikasi berperan penting dalam pembangunan pariwisata khususnya desa wisata melalui pemberdayaan Kelompok Sadar Wisata (Pokdarwis) (Putri \& Adinia, 2018). Pengembangan pariwisata dapat dikembangkan secara berkelanjutan melalui membangun kesadaran dan keahlian masyarakat untuk membuat usaha-usaha yang menjadikan produkproduk yang bisa diolah sebagai ciri khas atau oleh-oleh khas daerah tersebut.

Agar partisipasi masyarakat dapat dioptimalkan, maka seyogyanya dilakukan pembinaan dan peningkatan kualitasnya, baik melalui penyuluhan maupun pelatihan terhadap masyarakat yang berada di kawasan yang menjadi destinasi wisata. Masyarakat belum sepenuhnya menyadari manfaat dari pembangunan destinasi wisata secara langsung, diakibatkan oleh faktor kebiasaan dan budaya masyarakat setempat.
Kabupaten Kamparmerupakan satu diantara kabupaten tertua yang dikukuhkan bersamaan berdirinya Provinsi Riau. Sebagai daerah yang adat dan kebudayaan yang unik, masyarakat Kampar, khususnya di Kecamatan Kuok, masih menganut adat-istiadat yang menyerupai sistem adat yang ada di Minangkabau Sumatera Barat. Akan tetapi, mereka lebih menyebut diri mereka sebagai orang $O c u$, yang berbeda secara adat dari Minangkabau.

Kekhasan adat Ocu ini didukung oleh berbagai norma, nilai, tradisi dan budaya yang menarik, yaitu rumah lontiok, upacara adat, kesenian, dan berbagai aktivitas khusus seperti balimau kasai dan perlombaan pacu tongkang. Namun demikian, eksistensi kebudayaan ini ternyata kurang populer sehingga wisatawan dan masyarakat umum belum banyak mengenali dan mau berkunjung ke kawasan Desa Kuok. Padahal tidak hanya budaya, namun masih terdapat potensi atraksi wisata lain, yaitu berupa kawasan agrowisata jeruk dan jambu citra yang banyak ditemukan di daerah ini. Minimnya pengetahuan dan kunjungan masyarakat, menunjukkan perlunya pengelolaan komunikasi pemasaran pariwisata yang tepat terutama dalam mem-branding destinasi daerah ini sebagai lokasi yang layak dikunjungi. Hal ini akan sangat menantang bagi desa ini dalam mengembangkan potensi wisata yang terdapat di Kecamatan Kuok agar dapat dikenal luas oleh calon wisatawan baik dalam maupun luar daerah.

Terkait dengan ini, penulis berupaya untuk menguraikan komunikasi pariwisata dalam pengembangan destinasi wisata dalam konteks pengembangan desa wisata yang berbasis budaya di Kecamatan Kuok Kabupaten Kampar. Model komunikasi pariwisata yang berbasiskan kearifan lokal merupakan bagian dari praktik komunikasi yang secara praktis dapat memberikan nuansa pembaharuan kegiatan wisata selama ini yang berorientasi pada model "modern" yang berbasiskan perkembangan ilmu pengetahuan dan teknologi (Bakti et al., 2018; Nugraha et al., 2017).

Berdasarkan latar belakang tersebut, tujuan tulisan ini adalah untuk menjelaskan komunikasi pariwisata pemerintah daerah dalam mengembangkan destinasi wisata, menjelaskan bentuk partisipasi masyarakat dalam pengembangan destinasi wisata dan memahami model perencanaan komunikasi 
pariwisata Pulau Belimbing di Kecamatan Kuok Kabupaten Kampar.

\section{METODE PENELITIAN}

Penelitian ini menggunakan metode penelitian deskriptif kualitatif. Penelitian kualitatif ini bertujuan untuk menjelaskan fenomena sedalam-dalamnya melalui pengumpulan data sedalam-dalamnya, yang lebih ditekankan adalah persoalan kedalaman (kualitas) data bukan banyaknya (kuantitas) data (Kriyantono, 2014).

Penelitian ini berlokasi di Kawasan Desa Wisata Pulau Belimbing Kecamatan Kuok Kabupaten Kampar Provinsi Riau. Kegiatan penelitian ini dilaksanakan dalam kurun waktu dari bulan Mei hingga Desember 2019. Subjek penelitian ini adalah perwakilan aparat pemerintah yang berperan mengembangkan destinasi wisata yaitu kepala dinas Zulia Darma, Camat Kuok yaitu Drs. Darusmar, M.Si, kepala desa Kuok yaitu Khairisman. Selain itu ada perwakilan kelompok masyarakat sadar wisata (Pokdarwis) Anjungan Mato yaitu Sukirman, dan masyarakat desa setempat. Informaninforman penelitian ini dipilih secara purposif sesuai kebutuhan data dari penelitian ini. Sementara itu, objek dari penelitian ini adalah komunikasi pariwisata dalam pembangunan destinasi wisata di Kecamatan Kuok Kabupaten Kampar.

Penelitian ini dilakukan dengan cara mengumpulkan, menyusun, mengolah dan menginterpretasikan dan menganalisis data yang diteliti dengan merujuk pada prosedur-prosedur riset yang menghasilkan data kualitatif. Peneliti menyajikan data dalam bentuk pernyataan atau kalimat secara sistematis untuk menjelaskan substansi permasalahan, sehingga diperoleh gambaran yang jelas tentang komunikasi pariwisata dalam pembangunan destinasi wisata di Kecamatan Kuok Kabupaten Kampar Provinsi Riau. Penelitian ini menggunakan wawancara, observasi dan dokumentasi untuk pengumpulan datanya. Setelah data terkumpul, data-data penelitian ini dianalisis dengan komponen analisis data yang terdiri atas tiga sub-proses yang saling terkait, yaitu: data reduction, data display (penyajian data) dan verifikasi (penarikan kesimpulan) (Moleong, 2010). Proses ini dilakukan dengan melibatkan kegiatan verifikasi terus-menerus selama penelitian berlangsung yaitu sejak awal datang ke lokasi penelitian, selama pengumpulan data, dan selama proses penyusunan hasil penelitian. Untuk mendapatkan keabsahan data maka peneliti menggunakan teknik pemeriksaan yaitu triangulasi. Pengecekan ini dimaksudkan untuk menghindari kekeliruan dalam menginterpretasikan data.

\section{HASIL DAN PEMBAHASAN}

Pembangunan pariwisata memerlukan dukungan kebijakan komunikasi, dalam hal ini formulasinya harus mempertimbangkan keserasian program nasional (Cangara, 2013). Namun demikian, desentralisasi telah memberi legitimasi kepada setiap daerah untuk memproduksi atau menghasilkan berbagai kebijakan yang sesuai dengan kebutuhan daerah, termasuk di bidang pariwisata (Jupir, 2016).

Secara umum di Indonesia pengembangan pariwisata, diberikan wewenangnya kepada Dinas Pariwisata. Dinas Parwisata Kabupaten Kampar sebagaimana dijelaskan dalam Peraturan Daerah Kabupaten Kampar Nomor 6 tahun 2016 dan Peraturan Bupati Kampar Nomor 54 tahun 2016 berkedudukan, bertugas dan berfungsi yaitu "memimpin, mengkoordinasikan, mengawasi dan mengendalikan dalam menyelenggarakan sebagian urusan Pemerintah Kabupaten di Bidang Pariwisata dan Kebudayaan". Untuk menjalankan tugas pokok tersebut Dinas Pariwisata dan Kebudayaan menyelenggarakan beberapa fungsi: merumuskan kebijakan teknis; menyelenggarakan urusan pemerintahan dan pelayanan umum di bidang pariwisata dan kebudayaan; membina dan melaksanakan tugas bidang wisata dan budaya; dan melaksanakan pengembangan pariwisata dan kebudayaan.

Pemerintah Kabupaten Kampar telah membuat kebijakan dan mempromosikan beberapa destinasi wisata unggulan daerah. Pemerintah daerah menjadikan Pulau Belimbing sebagai destinasi wisata karena pertimbangan kawasan kampung tua ini memiliki ciri khas budaya dan adat istiadat yang terpelihara. Kecamatan Kuok memiliki potensi mengembangkan destinasi wisata karena sudah didukung oleh pengelolaan tujuan wisata secara mandiri atau swadaya oleh masyarakat seperti: Andalus Wisata Keluarga, Lubuk Kolam, 
Niagara Lubuk Nginio, dan Wisata Alam Puncak Tuah.

Sebagai andalan pemerintah daerah, Desa Wisata Pulau Belimbing dikembangkan dengan basis komunikasinya melalui membina Kelompok Sadar Wisata (Pokdarwis) Anjungan Mato. Daya tarik destinasi wisata ini adalah adanya rumah Lontiok. Objek Wisata Rumah Lontiok adalah salah satu tujuan wisata yang terdapat di Dusun Pulau Belimbing Desa Kuok Kecamatan Kuok Kabupaten Kampar. Rumah lontiok merupakan rumah adat khas dari masyarakat Kabupaten Kampar. Rumah Lontiok disebut juga dengan rumah lancang atau pancalang. Rumah lontiok mempunyai ciri seperti rumah panggung. Kata lontiok dalam Bahasa Indonesia yaitu lentik. Kata lontiok merujuk pada bentuk rumah yang melengkung atau bengkok, pada gambar 1 .

Rumah lontiok ini sudah lama dijadikan sebagai branding wisata daerah Kampar, namun belum dikembangkan secara maksimal sehingga belum dikenal dan terkelola dengan baik. Keberadaannya belum ditunjang dengan sarana dan prasarana yang memadai, seperti tidak adanya tempat istirahat bagi pengunjung, toilet/wc umum, tidak adanya homestay. Selain itu, tidak tersedianya tempat memperoleh cinderamata khas daerah untuk dibawa pulang oleh wisatawan. Pada dasarnya pariwisata merupakan produk bisnis modern. Jadi semua produk pariwisata ditujukan sebagai produk bisnis, mulai dari destinasi, ekonomi kreatif, transportasi, perhotelan, tempat rekreasi, dan atraksi seni yang dikemas menjadi paket wisata yang menarik, mengagumkan, menantang dan mengesankan bagi wisatawan (Bungin, 2015). Oleh karena itu, komunikasi menjadi sangat penting dalam menciptakan destinasi Pulau Belimbing sebagai produk utama andalan wisata daerah Kampar.

Padahal dengan strategi komunikasi yang tepat melalui memberdayakan masyarakat pedesaan dapat mengembangkan pariwisata lokal untuk menghasilkan perubahan sosial dan berkontribusi untuk meningkatkan partisipasi dan kesejahteraan masyarakat (Putri \& Adinia, 2018). Jadi komunikasi tidak saja berperan pada promosi pariwisata, namun semua komponen dan elemen pariwisata memerlukan komunikasi. Pariwisata memerlukan komunikasi untuk pengembangan aksesibilitas, destinasi, dan sumber daya lainnya kepada wisatawan dan



Sumber: Dokumentasi Pribadi, 2019

\section{Gambar 1 Rumah Adat Lontiok}

seluruh stakeholder pariwisata termasuk membentuk kelembagaan pariwisata (Bungin, 2015).

Ada tiga hal mendasar yang menjadi tujuan dan perhatian masyarakat agar pariwisata dapat berkesinambungan yakni aspek ekonomi, sosial dan lingkungan. Apabila ketiga aspek ini dapat terintegrasi dengan baik, maka pariwisata berkelanjutan akan terbentuk dengan sendirinya (Karta \& Suarthana, 2014). Destinasi wisata Rumah Lontiok di Pulau Belimbing Kecamatan Kuok, dalam pengembangannya terkendala pada beberapa hal. Hal itu diungkapkan Ketua Pokdarwis Anjungan Mato bapak Sukirman.

"Lahan di sini kan atas nama ulayat, sudah dari turun temurun. Kalau hibah lahannya tidak ada, Pemda tak mau membangunnya. Lahan ini diperlukan karena berguna untuk pembangunan sarana dan homestay, karena saat ini tamu yang ingin menginap di kampong ini cuma bisa menumpang menginap di rumah-rumah warga saja. Kendala kita kan tempat tidur, kasur. Hal ini sudah disampaikan kedinas. Kami disuruh buat proposal, sudah dibuat tapi belum ada realisasinya. Kalau penginapan dan tempat tidur banyak, tentu ada yang mau menginap, Cuma kita belum bisa menampung mereka. Seperti dari Malaysia dan Singapura. Padahal banyak dari mereka yang mau menginap di sini."

Wisatawan selain melihat rumah lontiok, juga bisa melihat objek wisata lain yang ada di Kecamatan Kuok. Merekabisa keliling kampung dengan odong-odong menikmati indahnya alam Dusun Pulau Belimbing yang terletak di pinggir Sungai Kampar. Tidak jauh dari desa wisata ini, mereka bisa juga menikmati beberapa objek 
wisata lain seperti air terjun Lubuk Nginio dan Lubang Kolam (lubang gelap) yaitu sebuah terowongan peninggalan Kolonial Belanda di Desa Merangin (Kampar, 2018).

Tak hanya itu, pengunjung sebenarnya juga bisa diajak melihat proses "menggelek" tebu atau menggiling tebu untuk diambil airnya dan akan dibuat madu atau manisan (lihat gambar 3). Pengunjung juga proses pengolahan kolangkaling. Namun banyaknya objek wisata inibelum dipasarkan secara terintegrasi oleh pemerintah setempat. Padahal komunikasi pemasaran terintegrasi sangat penting dilakukan, diiringi dengan pengelolaan destinasi yang tepat terhadap potensi objek-objek wisata budaya tersebut (Wang et al., 2009).

Oleh karena itu, pemahaman dan pengetahuan tentang sikap kelompok masyarakat lokal sangat penting dalam pembangunan pariwisata berkelanjutan sehingga dapat membantu proses perencanaan destinasi wisata (Lundberg, 2017). Pembinaan masyarakat, peningkatan fasilitas pendukung destinasi wisata, dan komunikasi pariwisata yang dilakukan pemerintah Kabupaten Kampar masih kurang gencar dan hanya bersifat seremonial. Padahal pembangunan komunikasi pariwisata dalam membangun kesadaran wisata masyarakat banyak mengandalkan pada pemerintah termasuk di bidang pariwisata (Jupir, 2016). Sebagai subordinat dari Negara Kesatuan Republik Indonesia, Pemerintah Daerah Kabupaten Manggarai Barat juga memiliki legitimasi yang sama untuk membuat berbagai kebijakan termasuk di bidang pariwisata. Pemerintah Kabupaten Manggarai Barat telah menetapkan pariwisata sebagai leading sector pembangunan dan membuat kebijakan pariwisata berbasis kearifan lokal untuk mendukung pengembangan pariwisata. Penelitian ini dilakukan dengan menggunakan metode penelitian kualitatif dengan pendekatan fenomenologi untuk menggambarkan, menganalisis dan menginterpretasikan sisisisi implementasi seperti partisipasi, jejaring, struktur keorganisasian, aktor, finansial, fasilitas, kondisi sosial, budaya, ekonomi dan politik serta kepentingan stakeholder. Teori yang digunakan untuk melakukan kajian ini adalah teori implementasi kebijakan Edward III. Berdasarkan teori ini, kesuksesan implementasi Kebijakan ditentukan oleh empat faktor, yaitu komunikasi, sumber daya, disposisi dan struktur

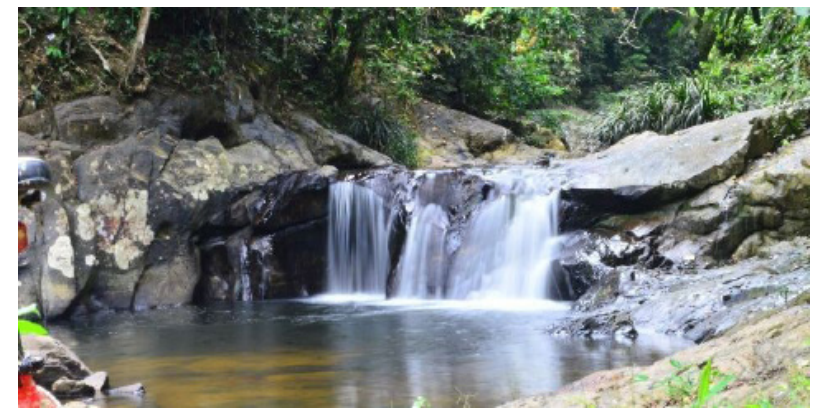

Sumber: Pemerintah Kampar (Kampar, 2018)

\section{Gambar 2 Air Terjun Lubuk Nginio}

birokrasi. Hasil penelitian menunjukkan bahwa ketersediaan sumber daya pendukung implementasi belum dialokasikan dengan jelas, komunikasi dan koordinasi belum berjalan optimal, kondisi eksternal (sosial, ekonomi, dan politik.

Masyarakat sudah memiliki kesadaran dalam pengembangan destinasi wisata seperti pengelolaan Andalus Wisata Keluarga dan kelompok sadar wisata (Pokdarwis) Anjungan Mato sebagai pengelola Desa Wisata Pulau Belimbing. Sebagai desa wisata, Dusun Pulau Belimbing tidak hanya menawarkan wisata alam dan agrowisatanya, namun bahkan lebih banyak mengandalkan pada wisata budaya. Bagi warga di Desa Wisata Pulau Belimbing ini, menyambut tamu dan wisatawan adalah bentuk sebagai penghormatan kepada pengunjung karena memuliakan tamu adalah sebuah keharusan. Sehingga banyak acara-acara adat dan seni tradisional masyarakat ditampilkan khusus untuk menyambut wisatawan yang datang.

Di Desa Wisata Pulau Belimbing ini, banyak terdapat kearifan lokal yaitu rumah adat Lontiok, ritual mandi balimau, Manggelek Tobu, dan tradisi-tradisi budaya lainnya. Manggelek Tobu misalnya, benda berukuran panjang ini, menggambarkan tradisi masyarakat tempo dulu, menggiling tebu untuk dijadikan manisan sebagai pengganti gula. Selain itu, ada proses pengolahan makanan dari buah aren yaitu kolang-kaling. Lokasinya tepat berdekatan dengan rumah adat (Umah Lontiok) terlihat masih berdiri kokoh berdiri di tengah perkampungan. Bangunan yang sarat dengan makna ini, sengaja dipertahankan untuk diperlihatkan kepada masyarakat luas bahwa Kabupaten Kampar memiliki sejarah dan budaya yang komplit. 
Berkaitan dengan ini, partisipasi masyarakat terlihat dari keaktifan kelompok sadar wisata (Pokdarwis) yang dibina pemerintah. Ketua Pokdarwis, Sukirman mengatakan bahwa penobatan Dusun Pulau Belimbing sebagai desa wisata karena desa ini masih memiliki banyak kearifan lokal yang terdapat di kampung itu yang berpotensi menarik wisatawan. Warga penduduk asli setempat berusaha mempertahankan tradisi. Pokdarwis Pulau Belimbing ini, mengemas atraksi budaya di daerahnya untuk dijadikan daya tarik wisata, karena masyarakat di sini menawarkan kepada calon pengunjung berbagai paket wisata dan budaya serta agrowisata. Namun demikian di sisi lain, beberapa masyarakat masih menginginkan tradisi ini tetap terjaga, sehingga mereka tidak menginginkan untuk dijadikan objek wisata yang dapat mengganggu budaya dan pemahaman masyarakat akibat intrusi budaya lain dari luar dengan datangnya wisatawan dari luar.

Kreativitas masyarakat melalui Pokdarwis membuat Pulau Belimbing ramai dikunjungi dan diminati orang banyak wisatawan. Komunikasi partisipatif masyarakat yang proaktif ini membantu komunikasi pariwisata dalam mengembangkan destinasi desa Pulau Belimbing. Di berbagai kesempatan, banyak media komunikasi dengan media sosial para pengunjung, warga dan Generasi Pesona Indonesia (Genpi) Kampar memperluas penetrasi pesan pemasaran tentang Pulau Belimbing dan objek wisata lainnya di Kecamatan Kuok. Tersedianya berbagai media komunikasi destinasi wisata, aksesibilitas, maupun saluran media SDM dan kelembagaan pariwisata seperti Pokdarwis ikut mempopulerkan destinasi wisata ini. Oleh karena itu, perencanaan komunikasi berperan

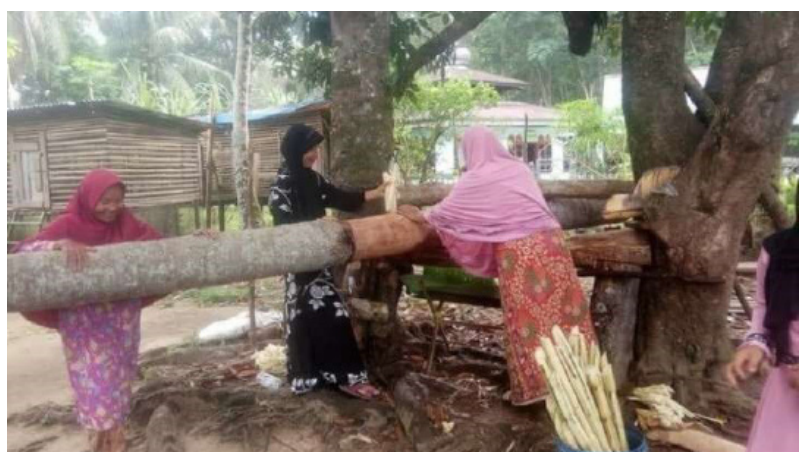

Sumber: Dokumentasi Pribadi, 2019

Gambar 3 Proses menggelek tebu penting dalam menyiapkan konten pesan yang tepat untuk disampaikan kepada masyarakat atau wisatawan, bahkan komunikasi internal kelompok Pokdarwis sendiri.

Partisipasi masyarakat lokal jelas sangat berpotensi untuk kegiatan dan pengembangan sebuah objek wisata (Kurniasari et al., 2013). Pertama, partisipasi dalam mengelola daya tarik wisata alam. Salah satu daya tarik desa Pulau Belimbing adalah Sungai Kampar. Sungai ini memiliki aliran arus yang sangat deras, meskipun dangkal. Sehingga ia cocok digunakan untuk bermain perahu karet dan menjadi tantangan tersendiri bagi wisatawan yang ingin mencobanya. Selain itu, Kawasan Pulau Belimbing memiliki potensi perkebunan yang baik terutama pohon karet dan kebun jeruk yang menjadi salah satu sumber kehidupan masyarakat. Wisatawan atau pengunjung dapat mempelajari berbagai macam cara menyadap pohon karet yang benar. Selain itu, kebun jeruk juga banyak dijumpai di daerah ini. Wisatawan akan diberi pengetahuan dan wawasan mengenai proses berkebun jeruk manis, dari menyemai biji, pemindahan bibit, penanaman hingga pemeliharaan tanaman jeruk. Wisatawan bisa diajak memanen atau memetik jeruk sendiri khususnya yang ingin membeli buah jeruk dengan harga sekitar 15 ribu/kg untuk dibawa pulang maupun dimakan langsung. Hal ini juga bisa dilakukan pada kebun jambu air Citra. Jambu air citra merupakan jenis jambu air yang digemari karena rasanya yang manis dan segar, jambu air citra yaitu mempunyai ukuran yang besar. Wisatawan yang ingin membeli buah jambu air citra dipatok harga sekitar 25 ribu/ $\mathrm{kg}$ untuk dibawa pulang maupun dimakan langsung.

Daya tarik alam dari sisi agrowisata lain berupa sawah masyarakat di desa ini. Kegiatan masyarakat di sawah ini pun dapat dijadikan potensi wisata untuk dimanfaatkan wisatawan belajar membajak sawah, menanam padi dan menuai padi pada musim panen. Kegiatan di sawah yang dilakukan di desa Pulau Belimbing masih menggunakan cara tradisional. Sehingga kegiatan-kegiatan pertanian dan perkebunan ini bisa menjadi atraksi wisata yang menarik bagi pengunjung terutama yang berasal dari kota terutama di kalangan anak-anak dari Kota Pekanbaru.

Kedua, partisipasi dalam mengelola daya tarik wisata budaya. Ada banyak atraksi wisata 
budaya yang dikelola masyarakat sebagai bentuk partisipasi dalam mengembangkan destinasi Pulau Belimbing sebagai destinasi wisata. Salah satu atraksi yang menarik adalah Bakela. Acara bakela atau makan bersama adalah bentuk tradisi masyarakat dalam menyelesaikan masalah secara bersama. Saat ini acara ini ditambah dengan kegiatannya pemberian santunan kepada anak yatim. Acara santunan anak yatim merupakan kegiatan dimana para tokoh masyarakat, ninik mamak, dan masyarakat dusun wisata Pulau Belimbing memberikan bantuan kepada semua anak-anak yatim yang ada di dusun desa wisata Pulau Belimbing berupa, perlengkapan sekolah, sarung (untuk mengaji), dan uang. Semua bantuan tersebut didapatkan dari kas daerah dan bantuan masyarakat sekitar.

Bentuk partisipasi masyarakat lain adalah pagelaran budaya atau seni pertunjukan. Seni pertunjukan sandiwara ini merupakan suatu kegiatan musiman yang dilakukan oleh warga Desa Kuok khususnya Pulau Belimbing. Sandiwaranya berisi cerita kerakyatan, para pemain atau para aktor sandiwara tidak memakai konsep dalam berperan. Pemainnya sendiri berasal dari warga Pulau Belimbing, yang sudah sering diundang dalam kegiatankegiatan pemerintah Kabupaten Kampar, nama kelompok sandiwara ini adalah "Lawaik Ombun". Pertunjukan sandiwara ini tidak diperbolehkan pemainnya dari kaum wanita, jika ada peran wanita, perannya akan dimainkan oleh laki-laki. Awal mula sejarah acara pentas sandiwara ini dibuat bertujuan untuk amal, tujuannya untuk mengumpulkan warga di suatu tempat supaya warga tidak pergi berkeluyuran pada saat lebaran. Acara sandiwara ini setiap tahunnya diadakan, tujuannya adalah untuk pemasukan kas kampung. Sampai sekarang pun para pemain sandiwara tidak dibayar, istilahnya peribahasa warga "awak kojo untuk masyarakat, makan nasi amak" dengan kata lain, dari warga untuk warga.

Atraksi budaya lain yang melibatkan masyarakat adalah pacu tongkang. Acara perlombaan pacu tongkang ini dilakukan selama tiga hari menjelang bulan suci Ramadhan. Selain tujuan perlombaan ini untuk bertanding, tujuan lainnya adalah untuk mengikat tali silaturahmi atau persaudaraan antar sesama masyarakat. Bila perlombaan pacu jalur di tempat lain mengikuti arus, lomba pacu tongkang di daerah ini sebaliknya malah melawan arus Sungai Kampar. Upacara budaya dalam bentuk ritual lainnya yang melibatkan masyarakat di dusun desa wisata Pulau Belimbing ini yaitu Balimau Kasai. Ritual ini adalah sebuah upacara tradisional yang istimewa bagi masyarakat Kampar untuk menyambut bulan suci Ramadan. Ritual ini tidak hanya menjadi tradisi saja tetapi juga sudah masuk sebagai event musiman yang dilaksanakan setiap tahunnya. Upacara tradisional ini selain bermakna ungkapan rasa syukur dan kegembiraan memasuki bulan puasa, juga bermakna penyucian dan pembersihan diri. Balimau Kasai sendiri merupakan ritual mandi dengan menggunakan air yang dicampur jeruk (limau).

Terkait dengan partisipasi masyarakat ini, perumusan dan implementasi kebijakan pembangunan desa wisata perlu melibatkan banyak stakeholder, seperti masyarakat, pemerintah, perusahaan atau CSR, Pokdarwis (kelompok sadar wisata) dan akademisi (Suyanto et al., 2019). Partisipasi stakeholder penting dalam mengemas, mengkampanyekan dan menularkan program pengembangan destinasi wisata karena tidak semua masyarakat dapat menerima program pemerintah. Dalam hal ini, komunikasi pariwisata belum melibatkan seluruh stakeholder. Meski demikian perguruan tinggi sudah memiliki peran dalam membantu mengembangkan destinasi wisata melalui pengabdian masyarakat oleh dosen atau Kuliah Kerja Nyata oleh mahasiswa. Padahal semua stakeholder termasuk wisatawan diharapkan mampu menerapkan sapta pesona yaitu menjaga kebersihan lingkungan, menjamu dengan sapa, senyum, ramah tamah, dan tertib dalam berinteraksi dengan wisatawan. Masyarakat perlu diberikan pembinaan lanjutan bahwa pariwisata membutuhkan kerja sama yang solid dari seluruh komponen masyarakat.

Partisipasi masyarakat dalam pelaksanaan atraksi budaya dapat memelihara nilainilai budaya Kabupaten Kampar, sehingga masyarakat khususnya generasi muda lebih mengenal budaya Kabupaten Kampar. Pemerintah Kabupaten Kampar memiliki kebijakan untuk mendukung kegiatan ini. Pada bulan Desember 2018, Pulau Belimbing Kecamatan Kuok Kabupaten Kampar menjadi tuan rumah. Sanggar "Lawuik Ombun" yang berasal dari Pulau Belimbing Kecamatan Kuok sebagai penyaji utama pada acara tersebut. 
Berbagai penampilan mulai dari tari tradisional, hingga musik komposisi khas Kabupaten Kampar disuguhkan oleh sanggar seni yang diketuai oleh Mak Ongah.

Komunikasi dengan memberdayakan masyarakat dan Pokdarwis dalam setiap atraksi wisata berperan penting dalam mengembangkan destinasi wisata berkelanjutan (Putri \& Adinia, 2018). Kegiatan pemberdayaan masyarakat ini berhubungan dengan upaya meningkatkan kemampuan dan memandirikan masyarakat untuk dapat mengaktualisasikan potensi wisata yang sudah dimiliki dalam rangka memegang kendali atas diri masyarakat dan lingkungannya. Pemberdayaan masyarakat dengan membina Pokdarwis Anjungan Mato jelas bentuk komunikasi pariwisata yang efektif dalam membangun destinasi. Sejalan dengan ini, komunikasi pembangunan kepariwisataan harus melibatkan masyarakat sebagai unsur utama sebagai pencerminan hakhak demokratis individu untuk melibatkan diri dalam pembangunan (Istiyanto, 2011).

Terkait dengan ini, program komunikasi memang tidak dapat menerpa semua masyarakat, akibatnya akan ada penerimaan dan ada penolakan di masyarakat (Nugraheni \& Widyaningrum, 2019). Tidak heran bila, Pokdarwis Anjungan Mato masih berbeda pandangan dengan masyarakat kelompok tua, sehingga banyak penolakan dari masyarakat kalangan yang tua. Padahal sebagai pelaku utama pengembangan desa wisata, Pokdarwis seharusnya bisa mengubah pandangan kelompok tua yang menolak Pulau Belimbing dijadikan sebagai destinasi wisata. Pokdarwis berperan penting dalam mengkampanyekan dan menularkan pada Pokdarwis yang lain di Kecamatan Kuok untuk mengembangkan destinasi sebagai pendukung objek wisata utamanya.

Model pengelolaan dan perencanaan komunikasi pariwisata pemerintah Kabupaten Kampar dalam mengembangkan destinasi wisata adalah dengan membentuk kelompok sadar wisata (Pokdarwis) di desa wisata yang ditentukan. Dalam hal ini, Dinas Pariwisata dan Kebudayaan Kabupaten Kampar sebagai pihak yang berwewenang dalam pengembangan destinasi wisata memiliki strategi yaitu: pengembangan objek pariwisata; peningkatan pembangunan sarana dan prasarana pariwisata; pengembangan jenis dan paket wisata; pelaksanaan koordinasi pembangunan objek pariwisata dengan lembaga/dunia usaha; pemantauan dan evaluasi pelaksanaan program destinasi promosi pariwisata; pengembangan destinasi wisata; pengembangan sosialisasi dan penerapan serta pengawasan standarisasi; dan pemeliharaan sarana dan prasarana pariwisata. Dari sini terlihat bahwa komunikasi pengembangan destinasi wisata belum terintegrasi menjadi satu kesatuan dengan komponen lain. Padahal pengembangan destinasi wisata yang berbasis seni, tradisi dan warisan budaya memerlukan komunikasi yang terintegrasi (Wang et al., 2009).

Ketergantungan dana bantuan dari pemerintah daerah faktanya malah menghambat. Masyarakat dan kelompok pengelola desa wisata menjadi terbelah karena bantuan dana pemerintah ini, akibat adanya penerimaan dan penggunaan yang tidak tepat sasaran. Pembinaan masyarakat memerlukan kebijakan dan kreativitas. Kebijakan dan komunikasi baik dari sisi pesan maupun bentuk media komunikasinya harus sejalan. Komunikasi pariwisata dan penggunaan media sosial menarik dikembangkan, tidak hanya dalam mengembangkan objek wisata namun penting dalam memelihara destinasi wisatanya dalam membangun citra brand destination. Penyebaran informasi melalui media sosial dapat menumbuhkan minat wisata dan menjalin kedekatan emosional untuk menumbuhkan kesadaran wisata masyarakat (Hamzah, 2013)

Pengembangan destinasi wisata Pulau Belimbingmembutuhkan sinergitas (kerjasama), perhatian, dan dukungan dari semua pihak baik dari masyarakat dan pemerintah. Rumah Lontiok sebagai peninggalan sejarah dan budaya untuk dilestarikan dan dikembangkan membutuhkan dukungan atraksi wisata lain yang bisa menjadi alternatif dan kombinasi selera wisatawan. Sebagai unggulan destinasi wisata Kabupaten Kampar, Pulau Belimbing dengan ikon-nya rumah lontiok, harus disinergikan dengan agrowisata dan wisata budaya untuk memperkuat komunikasi pemasarannya. Brand Pulau Belimbing akan terbentuk di benak masyarakat jika bentuk pesan dan salurannya yang dipilih tepat dan bervariasi.

Pengembangan destinasi ini sudah ditunjang dengan keunggulan potensi yang lain seperti wisata atraksi budaya dan alam seperti kebun jeruk dan karet sebagai wisata edukasi 
anak-anak kota yang tidak memiliki pengalaman dalam pertanian dan perkebunan. Pokdarwis dan masyarakat di desa Belimbing sudah mengembangkan beberapa kegiatan pariwisata, namun saat ini kegiatannya vakum. Hal ini terjadi karena terbelahnya sikap masyarakat, sebagian masyarakat terutama masyarakat tua (tokoh ninik mamak) berpikir bahwa jika kegiatan pariwisata ini terus dilanjutkan maka desanya akan menjadi seperti di Bali, terpapar budaya asing.

Pemerintah melalui dinas pariwisata dan Pokdarwis sudah melakukan komunikasi dengan mengkampanyekan dan membuat event-event atau atraksi pendukung. Samsurizal, sebagai sekretaris Pokdarwis Anjungan Mato yang juga pengelola tim kesenian telah bekerja sama dengan beberapa agen travel. Banyak kegiatan dan atraksi tradisi budaya dilakukan untuk penyambutan tamu dengan kesenian khas daerah. Wisatawan anak murid sekolah Darma Yuda dari Pekanbaru misalnya, ingin melihat rumah adat Lontiok dan kebiasaan masyarakat desa yang masih asli, serta rumah-rumah mereka yang masih unik dan tidak pernah mereka lihat di kota. Namun belakangan kegiatankegiatan seperti ini tidak dilanjutkan lagi karena ketakutan sebagian masyarakat akan pengaruh budaya wisatawan yang berbeda.

Terkait dengan ini, Pokdarwis sebagai agen perubahan sosial memiliki peranan sangat penting dalam pengembangan desa wisata yang berkelanjutan. Pemerintah melalui dinas pariwisata bersama dengan Pokdarwis diharapkan mampu memecahkan masalah dan mencari solusi terkait pengembangan destinasi wisata ini. Selain itu keduanya tetap bertanggung jawab mempromosikan destinasi wisata Pulau Belimbing dan memberikan pemahaman kepada tokoh masyarakat tua agar bisa melanjutkan pengembangan destinasi wisata yang sudah berkembang baik. Komunikasi pengembangan destinasi wisata harus tetap dilanjutkan agar ninik mamak atau masyarakat tua mau menerima perubahan. Komunikasi pariwisata harus tetap berkelanjutan dengan tetap memelihara tradisi dan adat istiadat masyarakat setempat. Oleh karena itu, dukungan sosial kaum tua ini menentukan keberhasilan pembangunan pariwisata, baik secara total (gabungan) maupun secara parsial (Rahmat et al., 2019).

Kelompok penggiat wisata budaya dapat bekerja sama, bersepakat, dan berkomitmen untuk mengembangkan destinasi wisata berbasis budaya dan kearifan lokal telah membentuk identitas kelompok yang kuat dan solid, atau dengan kata lain kelompok ini memiliki tingkat kohesivitas yang tinggi (Bakti et al., 2018). Oleh karena itu, dengan adanya pengembangan destinasi wisata Pulau Belimbing sebagai objek wisata tersebut, diharapkan mereka sadar bahwa daerahnya memiliki potensi untuk menjadi tempat destinasi wisata dan dapat memberikan dampak positif bagi perekonomian dan mereka semakin kompak.

Komunikasi yang intensif Pokdarwis mampu meyakinkan bahwa dengan adanya kegiatan pariwisata di daerahnya tidak mesti berubah menjadi seperti di Bali. Masyarakat didorong untuk bangga dengan adat istiadatnya dan memunculkan kearifan lokalnya. Misalnya tidak dibenarkan wisatawan datang yang mau masuk ke rumah lontiok dengan berpakaian yang minim (tidak menutup aurat yang pantas). Kalau ada wisatawan yang datang seperti itu diberi pakaian atau kain untuk menutup auratnya. Kain itu mungkin bisa hasil dari kerajinan masyarakat yang khas tradisi budaya masyarakat Kampar yang bisa dijual juga. Selain itu, pengembangan destinasi juga harus didukung oleh adanya kuliner atau oleholeh yang dihasilkan masyarakat setempat. Produknya dikemas dan diberi merek agar lebih menarik, karena merek adalah identitas atau pengenal suatu produk. Apalagi produkproduk yang dihasilkan oleh masyarakat tempatan menjadi buah tangan yang penting bagi wisatawan untuk dibawa pulang.

Penciptaan destinasi wisata sebagai langkah maju dalam pengembangan kegiatan pariwisata yang potensial untuk dilaksanakan di kawasan agrowisata dan permukiman penduduk Pulau Belimbing ini. Pokdarwis dan masyarakat Pulau Belimbing sebagai sasaran utama dan masyarakat di Kecamatan Kuok kurang dilakukan pembinaan secara berkelanjutan oleh pemerintah daerah setempat. Sebagai opinion leader, Pokdarwis berperan sebagai pelestari budaya dan agen utama perubahan untuk mengembangkan potensi wisata sekaligus memperoleh hasil ekonomi dari kedatangan wisatawan. Hal ini dilakukan dengan cara memberikan penyuluhan tentang pentingnya inovasi produk-produk hasil perkebunan dan tata kelola kawasan agrowisata jeruk secara sederhana untuk keasrian lingkungan hidup dan 
kelangsungan bisnis agrowisata. Oleh karena itu, masyarakat diharapkan dapat mengembangkan budidaya jeruk, Taman Agrowisata Jeruk Bangkok Pulau Belimbing. Tagline bangkok sebagai akronim dari kata Bangkinang Kuok yang biasa digunakan oleh anak muda untuk menyebut kawasan desa Kuok.

Jika brand identity yang dikembangkan Pokdarwis Anjungan Mato, pemerintah dan masyarakat setempat berhasil, baik dengan brand destinasi wisata, tagline atau slogan, dan logo dilakukan dengan baik, maka bukan tidak mungkin ia menjadi ikon besar bagi Kabupaten Kampar bahkan Riau. Pokdarwis Pulau Belimbing sudah mempromosikan pariwisata daerah melalui media sosial Instagram dan Facebook. Namun seiring perkembangan zaman, komunitas ini dapat mengikuti trend yang ada di dunia maya yang dimana netizen hobi melakukan foto-foto di lokasi objek wisata lalu meng-upload nya ke media sosial. Berdasarkan diskusi dengan anggota dan stakeholderstakeholder terkait, maka diputuskan untuk membangun nama Pulau Belimbing sebagai brand destinasi wisata di Kampar. Komunitas

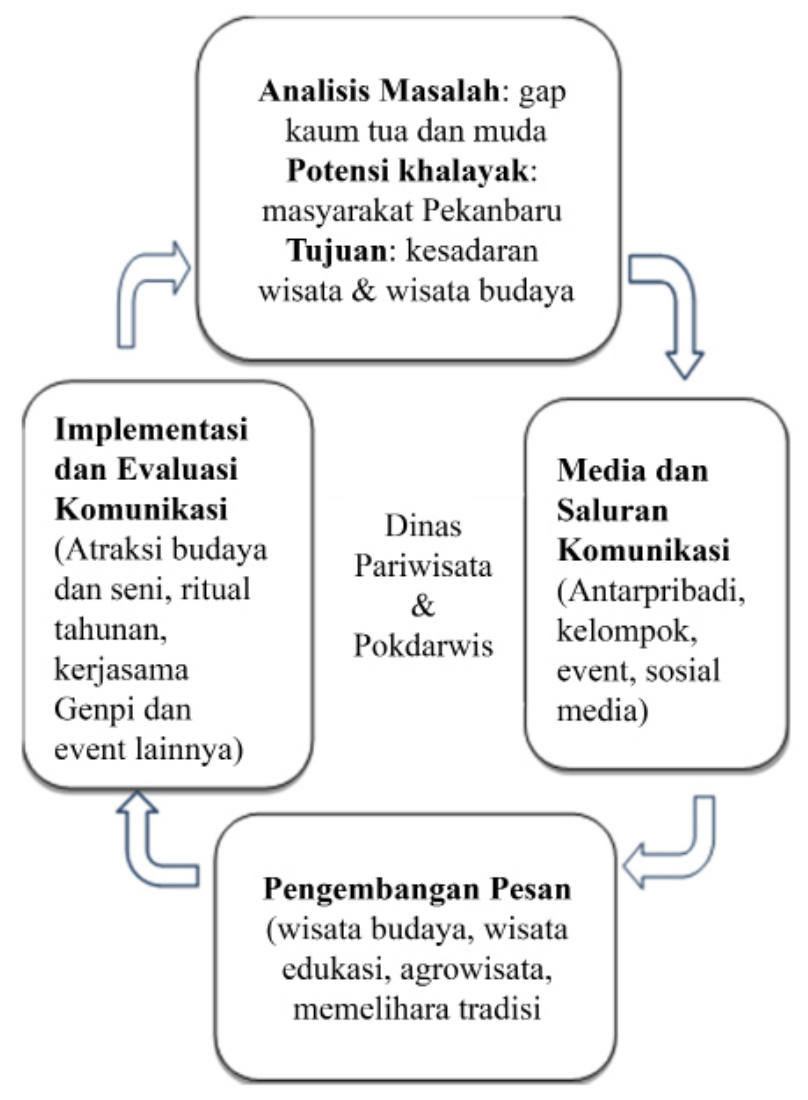

Sumber: Data Penelitian, 2019

Gambar 4 Model perencanaan komunikasi pemasaran destinasi wisata Kuok
GenPI Kampar juga melakukan upaya untuk mempromosikan nama brand Pulau Belimbing. Upaya yang dilakukan akan lebih tepat dengan menentukan tema besar yang akan diangkat dan menentukan segmentasi khalayak dalam komunikasi pariwisata.

Destinasi wisata Pulau Belimbing masih kurang Instagramable untuk menarik anakanak muda berkunjung dan ber-swafoto. Padahal anak muda mudah mempunyai konten baru berupa foto-foto yang akan di-upload ke media sosial yang mereka miliki. Kegiatan komunikasi destinasi wisata seperti ini akan cepat tersebar di kalangan anak-anak muda yang saat ini lebih banyak menggunakannya sebagai saluran komunikasi utama. Pemanfaatan media sosial ini, selain lebih sederhana dan fleksibel, ia juga mudah dibawa ke mana saja, baik dalam penyimpanan, penerimaan, dan pengiriman pesan sangat efektif dalam pengembangan destinasi wisata (Bakti et al., 2018). Brand destinasi yang terbentuk di media sosial ini memiliki kekuatan, yaitu melalui keunikan identitas dan menciptakan destinasi wisata yang kuat dan populer.

Komunikasi pariwisata merupakan proses yang berkelanjutan yang memerlukan pemantauan tren baru secara fleksibel terhadap perubahan (Karta \& Suarthana, 2014). Beberapa strategi dibutuhkan untuk meningkatkan brand image dan awareness untuk memperoleh keunggulan kompetitif. Strategi utamanya adalah pemilihan saluran komunikasi yang tepat, untuk mengembangkan hubungan jangka panjang dengan kelompok sasaran (Štefko et al., 2015). Oleh karena itu, komunikasi pariwisata melalui berbagai saluran komunikasi perlu terus dilakukan untuk melakukan penyadaran dan pembinaan kepada warga masyarakat untuk menghargai budaya aslinya sendiri dan kemampuan menangkal budaya luar, yaitu dengan penyuluhan kelestarian seni tari, adat istiadat, makanan dan minuman tradisional, termasuk di dalamnya penggunaan baju adat dan rumah lontiok sebagai atraksi pameran budaya khas Ocu Kuok. Pemerintah melakukan pembinaan masyarakat seperti kepada anggota Pokdarwis Anjungan Mato bertujuan agar mampu menjadi agen perubahan dan menularkan pada Pokdarwis yang lain di Kecamatan Kuok. Pembinaan juga harusnya mengajarkan bagaimana cara memanfaatkan media jejaring sosialnya sebagai ajang promosi 
agrowisata dan wisata. Banyaknya ritual dan tradisi budaya serta pertunjukan kesenian yang dimiliki, lewat sajian budaya yang ruitn seperti dari sanggar seni Leuwik Embun harusnya dipasarkan dan dikampanyekan di media sosial. Begitu juga dengan kampanye seperti Wisata Agro-Cultural Pulau Belimbing bisa menjadi tema utama dalam kampanye di berbagai kesempatan yang dilakukan. Kampanye diperlukan komunikasinya menggunakan kerangka pikir sistematis dan asas-asas strategis fundamental (Berger et al., 2014).

Kegiatan komunikasi pariwisata pengembangan destinasi menjadi tanggung jawab semua komponen masyarakat atau stakeholder. Pemerintah seharusnya menggalakkan pembinaan dan kampanye untuk menerapkan sapta pesona dengan menjaga kebersihan lingkungan, menjamu dengan sapa, senyum, ramah tamah, tertib dalam berinteraksi dengan wisatawan. Masyarakat perlu diberikan pembinaan berkelanjutan karena pariwisata membutuhkan kerja sama yang solid dari seluruh komponen masyarakat untuk berkembang dan menghasilkan nilai tambah secara ekonomi dan sosial dalam kehidupannya.

\section{SIMPULAN}

Komunikasi pariwisata dalam pengembangan destinasi wisata Pulau Belimbing Kecamatan Kuok di Kabupaten Kampar dilakukan dengan cara membina dan memberdayakan kelompok sadar wisata (Pokdarwis), melibatkan partisipasi masyarakat sekitar destinasi wisata, dan kampanye wisata yang mengusung tema Wisata AgroCultural. Dalam melakukan perencanaan komunikasi pariwisata di kawasan destinasi wisata Pulau Belimbing sebaiknya pemerintah mengembangkan komunikasi yang lebih kreatif, terintegrasi dan berkelanjutan dalam melakukan pembinaan menyesuaikan pada aspirasi masyarakat setempat untuk mendapatkan capaian yang optimal baik dari sisi ekonomi maupun brand identity Pulau belimbing sebagai destinasi wisata yang berbasiskan budaya lokal.

\section{DAFTAR PUSTAKA}

Ali, A. (2018). Travel and tourism: Growth potentials and contribution to the GDP of Saudi Arabia. Problems and Perspectives in Management, 16(1), 417-427. https:// doi.org/10.21511/ppm.16(1).2018.39

Bakti, I., Sumartias, S., Damayanti, T., \& Nugraha, A. R. (2018). Pengembangan model komunikasi pariwisata berbasis kearifan lokal di kawasan Geopark Pangandaran. Jurnal Kajian Komunikasi, 6(2), 217. https://doi.org/10.24198/jkk. v6i2.18459

Berger, C. R., Roloff, M. E., \& RoskosEwoldsen, D. R. (2014). The handbook of communication science. USA: Wadsworth. Terjemahan Derta Sri Widowatie. 2014. Handbook Ilmu Komunikasi. Nusa Media.

Boes, K., Buhalis, D., \& Inversini, A. (2016). Smart tourism destinations: ecosystems for tourism destination competitiveness. International Journal of Tourism Cities, 2(2), 108-124. https://doi.org/10.1108/ IJTC-12-2015-0032

Bungin, B. (2015). Komunikasi pariwisata: pemasaran dan brand destinasi. Jakarta: Prenada Media Group.

Cangara, H. (2013). Perencanaan dan strategi komunikasi. Raja Grafindo Persada.

Fan, S., Chen, Y., Su, X., \& Cheng, Q. (2018). A study of effects of ecotourism environment image and word of mouth on tourism intention. Ekoloji, 27(106), 599-604.

Genç, R., \& Genç, E. A. (2017). Marketoriented innovations in tourism. Research in Hospitality Management, 7(1), 51-57. https://doi.org/10.1080/22243534.2017.13 55606

Hamzah, Y. I. (2013). Potensi media sosial sebagai sarana promosi interaktif bagi pariwisata Indonesia. Jurnal Kepariwisataan Indonesia, 8(3), 1-9. http://www.kemenpar.go.id/userfiles/JKI Vol 8 No 32013 - Potensi Media Sosial Sebagai Sarana Promosi Interaktif Bagi Pariwisata Indonesia.pdf

Istiyanto, S. B. (2011). Komunikasi pemerintah daerah dalam program pembangunan daerah wisata pantai pascabencana. Jurnal Ilmu Komunikasi, Vol 9(No 1), 16-27.

Jupir, M. M. (2016). Implementasi kebijakan pariwisata berbasis kearifan lokal (studi di Kabupaten Manggarai Barat). Journal of Indonesian Tourism and Development Studies, 1(1), 28-38. https://doi. org/10.21776/ub.jitode.2013.001.01.05 
Kampar, K. (2018). Singgah di Kuok, nikmati pemandangan nan elok. http://kamparkab. go.id/home/vlama/berita/kuok/singgah-dikuok-nikmati-pemandangan-nan-elok.html

Karta, N. L. P. A., \& Suarthana, I. K. P. (2014). Strategi komunikasi pemasaran ekowisata pada destinasi wisata dolphin hunting lovina. Jurnal Manajemen, Strategi Bisnis Dan Kewirausahaan, 8(1), 45-51.

Kriyantono, R. (2014). Teknik praktis riset komunikasi. Jakarta: Prenada Media.

Kurniasari, E., Rustiadi, E., \& Tonny, F. (2013). Strategi pengembangan ekowisata melalui peningkatan partisipasi masyarakat; studi kasus komunitas kelurahan kalimulya Kota Depok. 5(2).

Liu, C. H. S. (2018). Examining social capital, organizational learning and knowledge transfer in cultural and creative industries of practice. Tourism Management, 64, 258-270. https://doi.org/10.1016/j. tourman.2017.09.001

Lundberg, E. (2017). The importance of tourism impacts for different local resident groups: A case study of a Swedish seaside destination. Journal of Destination Marketing and Management, 6(1), 46-55. https://doi. org/10.1016/j.jdmm.2016.02.002

Moleong, L. J. (2010). Metode penelitian kulaitatif. Bandung: Remaja Rosdakarya.

Nugraha, A. R., Perbawasari, S., \& Zubair, F. (2017). Model komunikasi pariwisata yang berbasiskan kearifan lokal. Jurnal The Messenger, 9(2), 231. https://doi. org/10.26623/themessenger.v9i2.468

Nugraheni, Y., \& Widyaningrum, A. Y. (2019). Dinamika sikap warga atas program csr bank sampah Gunung Anyar Surabaya. Jurnal Studi Komunikasi (Indonesian Journal of Communications Studies), 3(1), 41. https://doi.org/10.25139/jsk.v3i1.1419

Putri, F. A., \& Adinia, N. C. (2018). The role of communication in sustainable development tourism: a case study on community-based tourism (pokdarwis) in Nglanggeran Village. Jurnal Komunikasi Indonesia,
7(2), 153-161. https://doi.org/10.7454/jki. v7i2.9795

Rahmat, A., Komariah, K., \& Setiawan, W. (2019). Komunikasi dan dukungan sosial di lingkungan masyarakat terdampak pembangunan Waduk Jatigede Sumedang. Jurnal Kajian Komunikasi, 7(1), 110. https://doi.org/10.24198/jkk.v7i1.21096

Ridlwan, M. A., Muchsin, S., \& Hayat, H. (2017). Model pengembangan ekowisata dalam upaya pemberdayaan masyarakat lokal. politik Indonesia: Indonesian Political Science Review, 2(2), 141. https:// doi.org/10.15294/jpi.v2i2.9933

Štefko, R., Királ'ová, A., \& Mudrík, M. (2015). Strategic marketing communication in pilgrimage tourism. Procedia - Social and Behavioral Sciences, 175, 423-430. https:// doi.org/10.1016/j.sbspro.2015.01.1219

Strydom, A. J., Mangope, D., \& Henama, U. S. (2019). Making community-based tourism sustainable: Evidence from the Free State province, South Africa. Geojournal of Tourism and Geosites, 24(1), 7-18. https:// doi.org/10.30892/gtg.24101-338

Suyanto, E., Lestari, S., Wardiyono, F., Wuryaningsih, T., \& Widyastuti, T. R. (2019). Community participation model in formulating cross-potential mangrove ecotourism policies supporting kampung laut sustainable tourism village. 13(8), 1-9. https://doi.org/10.9790/2402-1308010109

Wang, Y. J., Wu, C., \& Yuan, J. (2009). The role of integrated marketing communications (IMC) on heritage destination visitations. Journal of Quality Assurance in Hospitality and Tourism, 10(3), 218-231. https://doi. org/10.1080/15280080902988048

Yasir, Nurjanah, Salam, N. E., \& Yohana, N. (2019). Kebijakan komunikasi dalam membangun destinasi dan masyarakat sadar wisata di kabupaten bengkalis. Jurnal Studi Komunikasi (Indonesian Journal of Communications Studies), 3(November), 424-443. https://doi.org/10.25139/ 